\title{
Video-assisted thoracic surgery in hemothorax evacuation after cardiac surgery or cardiac interventions
}

\author{
Aladdin Bashir, Omar Daraghma, Zbigniew Brzeziński, Dawid Imiełowski, Piotr Daszkiewicz, \\ Witold Gwoźdź, Jerzy Stupała, Paweł Tomaszewski, Jacek Kaperczak
}

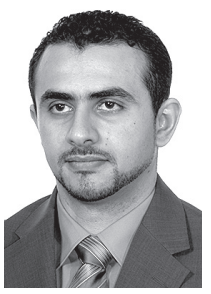

Department of Cardiac Surgery, Clinical University Hospital, Opole, Poland

Kardiochirurgia i Torakochirurgia Polska 2017; 14 (3): 154-157

\begin{abstract}
Introduction: Cardiac surgery and cardiac interventions are associated with the risk of iatrogenic complications, including hemothorax. Minimally invasive methods of evacuating hemothorax include video-assisted thoracic surgery (VATS).

Aim: This paper presents this method and provides its detailed analysis.

Material and methods: The VATS procedures were used to evacuate hemothorax in 8 patients ( 7 after cardiac surgery and 1 after a cardiac intervention). Complete three-port VATS was performed in 7 patients, while 1 patient underwent assisted VATS due to a large number of adhesions.

Results: On average, the repeat procedures were performed on the 20 th postoperative day $\left(10^{\text {th }}-58^{\text {th }}\right.$ postoperative day). In $6(75 \%)$ cases the VATS intervention was the third surgical intervention performed. One patient, operated on 12 days after the original procedure, was diagnosed with active arterial bleeding, which required conversion to a classic procedure using median sternotomy. No postoperative wound infection was noted. Complete hemothorax removal was achieved in all patients.

Conclusions: Classic median sternotomy is the standard approach for hemothorax evacuation. However, it may sometimes be burdened with a high perioperative risk due to massive mediastinal adhesions in the late postoperative period. Additionally, access through the postoperative wound appears to be associated with a higher risk of local infection and sternal instability. Hemodynamically stable patients in the late postoperative period, with stable sternums and healed postoperative wounds, are good candidates for VATS aiming to evacuate hemothorax. The VATS is an effective procedure for evacuating hemothorax.
\end{abstract}

Key words: hemothorax, video-assisted thoracic surgery, sternotomy, cardiac surgery.

\section{Streszczenie}

Wstęp: Zabiegi kardiochirurgiczne oraz interwencje kardiologiczne wiążą się z ryzykiem wystąpienia powikłań jatrogennych, m.in. krwiaka jamy opłucnej. Do małoinwazyjnych metod ewakuacji krwiaka jamy opłucnej można zaliczyć zabiegi wideotorakoskopowe (VATS).

Cel: W pracy przedstawiono metodę VATS i poddano ją szczegółowej analizie.

Materiat i metody: Zabieg VATS w celu ewakuacji krwiaka jamy opłucnej wykonano u 8 pacjentów: 7 po zabiegach kardiochirurgicznych i 1 po interwencji kardiologicznej. Zastosowano cVATS z wykorzystaniem 3 portów u 7 pacjentów oraz aVATS u 1 pacjenta ze względu na dużą liczbę zrostów.

Wyniki: Pacjentów operowano ponownie średnio w 20. dobie po pierwotnej operacji (10.-58. doby). U 6 (75\%) pacjentów VATS stanowiła trzecią interwencję chirurgiczną. U jednego z pacjentów, operowanego w 12. dobie po zabiegu, stwierdzono czynne krwawienie o charakterze tętniczym, co wiązało się z koniecznością konwersji do zabiegu klasycznego przez sternotomię pośrodkową. Nie stwierdzono infekcji ran operacyjnych. Krwiak usunięto w całości u wszystkich pacjentów.

Wnioski: Standardowym dostępem do ewakuacji krwiaka jamy opłucnej jest dostęp klasyczny przez sternotomię pośrodkową. Ewakuacja krwiaka z tego dostępu bywa jednak obarczona dużym ryzykiem okołooperacyjnym z powodu masywnych zrostów śródpiersia w odległym okresie pooperacyjnym. Dodatkowo wydaje się, że dostęp przez ranę pooperacyjną jest związany z większym ryzykiem wystąpienia infekcji miejscowej i niestabilności mostka. Pacjenci w odległym okresie po operacji, w stabilnym stanie hemodynamicznym, ze stabilnym mostkiem oraz wygojoną raną pooperacyjną są dobrymi kandydatami do VATS w celu ewakuacji krwiaka jamy opłucnej. Zabieg VATS jest skuteczną metodą ewakuacji krwiaka jamy opłucnej.

Słowa kluczowe: krwiak opłucnej, wideotorakoskopia, sternotomia, kardiochirurgia.

Address for correspondence: Aladdin Bashir, Department of Cardiac Surgery, Clinical University Hospital, Al. Wincentego Witosa 26, 45-418 Opole, Poland, phone: +48 511119 951, e-mail: alaabsr@hotmail.com

Received: 3.01.2017, accepted: 9.08.2017. 


\section{Introduction}

Cardiac surgery and cardiac interventions are associated with the risk of iatrogenic complications, including hemothorax. Hemothorax may develop due to direct vascular damage incurred during large vessel catheterization, increased postoperative bleeding, and pleural puncture (thoracocentesis) performed to evacuate fluid (most often resulting from exacerbation of circulatory insufficiency). Thromboembolic prevention, required in this patient group, increases the risk of bleeding during such interventions. The pleural cavity may accommodate large amounts of blood, up to $30-40 \%$ of the volume of blood in circulation [1]. Factors predisposing to hemothorax include coagulation disorders, chronic obstructive pulmonary disease, and limited respiratory rehabilitation.

Classic median sternotomy is the standard approach for hemothorax evacuation. However, it may sometimes be burdened with a high perioperative risk due to massive mediastinal adhesions in the late postoperative period. Additionally, access through the postoperative wound appears to be associated with a higher risk of local infection. Hence the need for other, less invasive surgical methods such as video-assisted thoracoscopic surgery (VATS). This paper presents this method and provides its detailed analysis.

\section{Diagnostics}

The standard management for all patients after cardiac surgery is to perform a thoracic $X$-ray examination in the antero-posterior (AP) projection within the first 2 postoperative days. Subsequent $\mathrm{X}$-ray examinations are performed depending on the patient's general condition, respiratory fitness, drainage, and results of previous examinations. Targeted photographs are taken as well. If the presence of fluid/hematoma is suspected based on the X-ray photograph, ultrasonography (echocardiography) is conducted with particular attention to the pericardium and the pleural cavity. Pleural cavity puncture is performed under ultrasonographic control. If there is no improvement, pleural drainage is indicated. In the case of encysted fluid, drainage is performed under USG control in order to select the optimal site for intervention. The final assessment of the hemothorax is performed using chest computed tomography (CT) with contrast (Fig. 1). This examination was performed in all patients before they were qualified for the VATS procedure.

\section{Surgical methods and approaches}

Methods of evacuating hemothorax include the administration of fibrinolytics into the pleural cavities, pleural drainage, and surgical methods [2]. The latter can be divided into classic and minimally invasive methods. The most commonly employed classic method is hemothorax evacuation through the median sternotomy wound or via lateral thoracotomy. Median sternotomy is a longitudinal incision dividing the sternum. This approach is routinely used in cardiac surgery procedures. It ensures best access both to the mediastinum and the pleural cavities (good conditions for evacuating hemothorax and decompressing pericardial tamponade with concurrent refixation of the sternum in the case of its dehiscence).

Minimally invasive methods include video-assisted thoracic surgery (VATS), which can be divided into assisted VATS (aVATS), using small ports $(1.5-2 \mathrm{~cm})$ and lateral minithoracotomy $(2-6 \mathrm{~cm})$, and complete VATS (cVATS), using 2-4 ports (1-2 cm in size) [3]. The standard VATS technique used in thoracic surgery patients has been modified at our department in order to achieve optimal conditions in cardiac surgery patients. The following stages of the procedure were established at our department:

1. Intubation with a double-lumen endotracheal tube. The standard procedure is to disconnect the lung on the side affected by hemothorax before trocars are introduced.

2. The patient is positioned on the operating table; the side with the hemothorax is elevated by $30-45^{\circ}$ (Fig. 2). This angle results in reduced pressure on the sternum (patients after median sternotomy) and ensures the possibility of

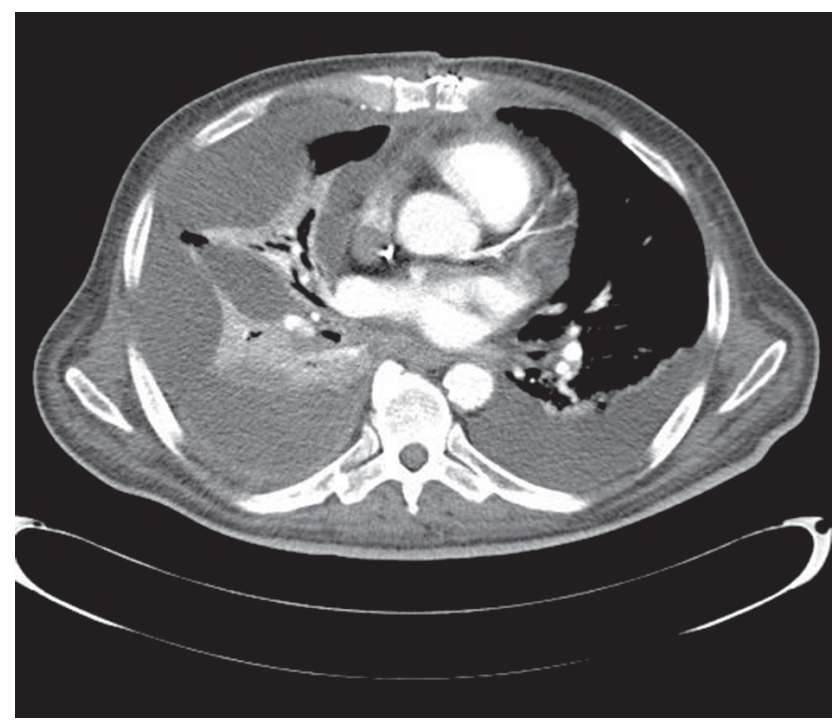

Fig. 1. Chest computed tomography: right-sided hemothorax

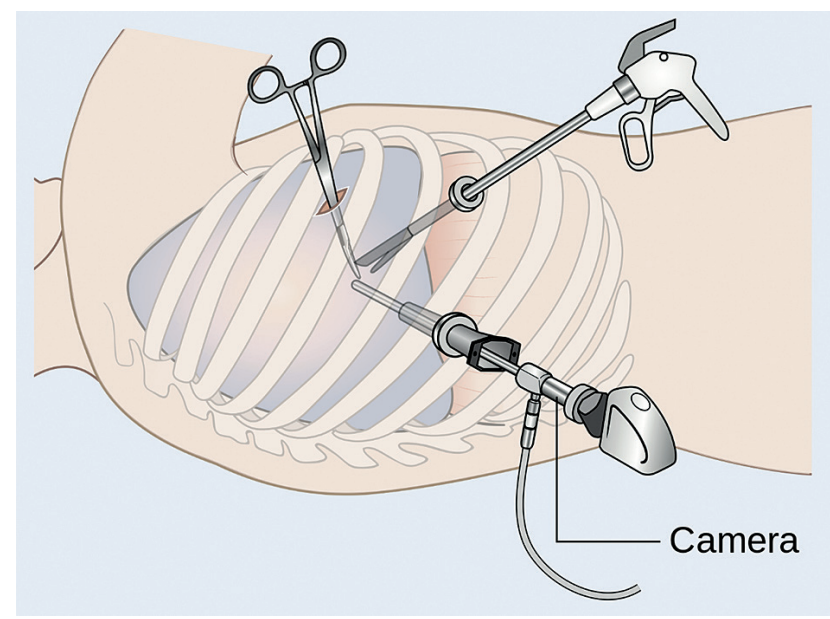

Fig. 2. Positioning the patient for video-assisted thoracic surgery; the side with the hematoma is elevated by $30-45^{\circ}$ 


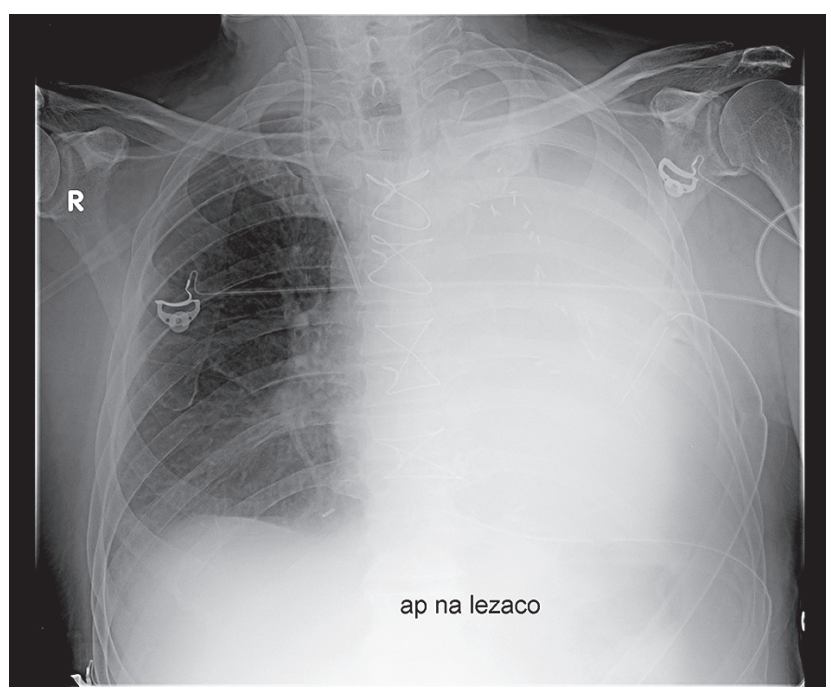

Fig. 3. Second control chest X-ray in a patient after video-assisted thoracic surgery, taken after the patient was disconnected from the respirator

conversion to a classic procedure using median sternotomy without the need for changing the patient's position. Thoracic surgery patients are placed on their side.

3. Cleaning the surgical field is conducted in the same manner as in the case of standard median sternotomy procedures.

4. An approximately $2-\mathrm{cm}$ incision is made at a location that provides optimal visualization of the hemothorax (most commonly in the $3^{\text {rd }}$ intercostal space when the hemothorax affects the lower part of the pleural cavity or the $7^{\text {th }}$ intercostal space when the upper part is affected). A trocar and a video camera are introduced.

5. Subsequent incisions (usually two) are made, and subsequent trocars are introduced under visual control. Lateral minithoracotomy can be performed.

6. Hemothorax is evacuated using endoscopic tools. The most often employed tools include graspers, dissectors, and vacuum drains.

7. A drain is introduced into the pleural cavity under camera control. In the case of massive adhesions, two drains are introduced: into the costophrenic angle and the upper part of the pleural cavity.

8. The wound is cleaned and dressed.

Below we analyze this treatment method.

\section{Aim}

This paper presents VATS in hemothorax evacuation after cardiac surgery or cardiac interventions and provides its detailed analysis.

\section{Material and methods}

In the analyzed group, the procedures were urgent in $75 \%$ of cases. The mean age of the patients was 73 years. The patients were burdened with additional conditions (type 2 diabetes mellitus - 37\%; arterial hypertension - 62\%; ischemic stroke $-25 \%$ ), increasing the perioperative risk, which amounted to $4.2 \%$ according to EuroScore II. Thromboembolic prophylaxis was provided to all patients. Antithrombotic treatment was necessary in half of the patients due to the presence of valvular prostheses or atrial fibrillation. Pleural puncture (thoracocentesis), performed to evacuate fluid, proved to be the cause of hemothorax development in 4 (50\%) patients. Limited respiratory rehabilitation was an important factor leading to atelectasis in $2(25 \%)$ patients who had previously suffered from a stroke with hemiparesis.

The process of qualifying patients for VATS included the consideration of the need for minimizing surgical injury and reducing the likelihood of damage to heart structures previously operated on and affected by postoperative adhesions, such as coronary artery bypass grafts or the right ventricle in patients in the late postoperative period or after a second sternotomy.

\section{Results}

Pleural drainage proved unsuccessful in evacuating hemothorax. On average, the repeat procedures were performed on the $20^{\text {th }}$ postoperative day $\left(10^{\text {th }}-58^{\text {th }}\right.$ postoperative day). In 6 (75\%) cases, the VATS intervention was the third surgical intervention performed (the secondary interventions were associated with tamponade or postoperative bleeding). Three-port cVATS was performed in 7 patients, while aVATS was employed in 1 patient due to a large number of adhesions. One patient, operated on 12 days after the original procedure, was diagnosed with active arterial bleeding, which required conversion to a classic procedure using median sternotomy. The source of the bleeding was an intercostal artery. In the case of 1 (12.5\%) patient, the second control chest X-ray, taken after extubation, suggested the development of hemothorax on the $2^{\text {nd }}$ day after VATS (Fig. 3); this diagnosis was confirmed by chest CT. The patient was operated on using classic median sternotomy. Intraoperative evaluation did not confirm the presence of hemothorax, but atelectasis of the whole lung was revealed. Complete hemothorax removal was achieved in all patients (Fig. 4).

Postoperative wound infection was not found in any of the patients.

\section{Discussion}

Isolated hemothorax after cardiac surgery is a rare postoperative complication. In the presented material, it occurred in $0.35 \%$ of the patients operated on at the Department of Cardiac Surgery between 2013 and 2016. Hemothorax evacuation with surgical methods (classic or VATS) is recommended when drainage is unsuccessful [4] and the diagnosis is confirmed by chest tomography [5].

Minimally invasive VATS is a widely used treatment method in thoracic surgery. The VATS was compared with thoracotomy with regard to lobectomies; the former method was characterized by lower perioperative risk associated with the procedure [6-8], shorter hospitalization [9], less pain [10], earlier recovery [10, 11], lower costs [12], and bet- 

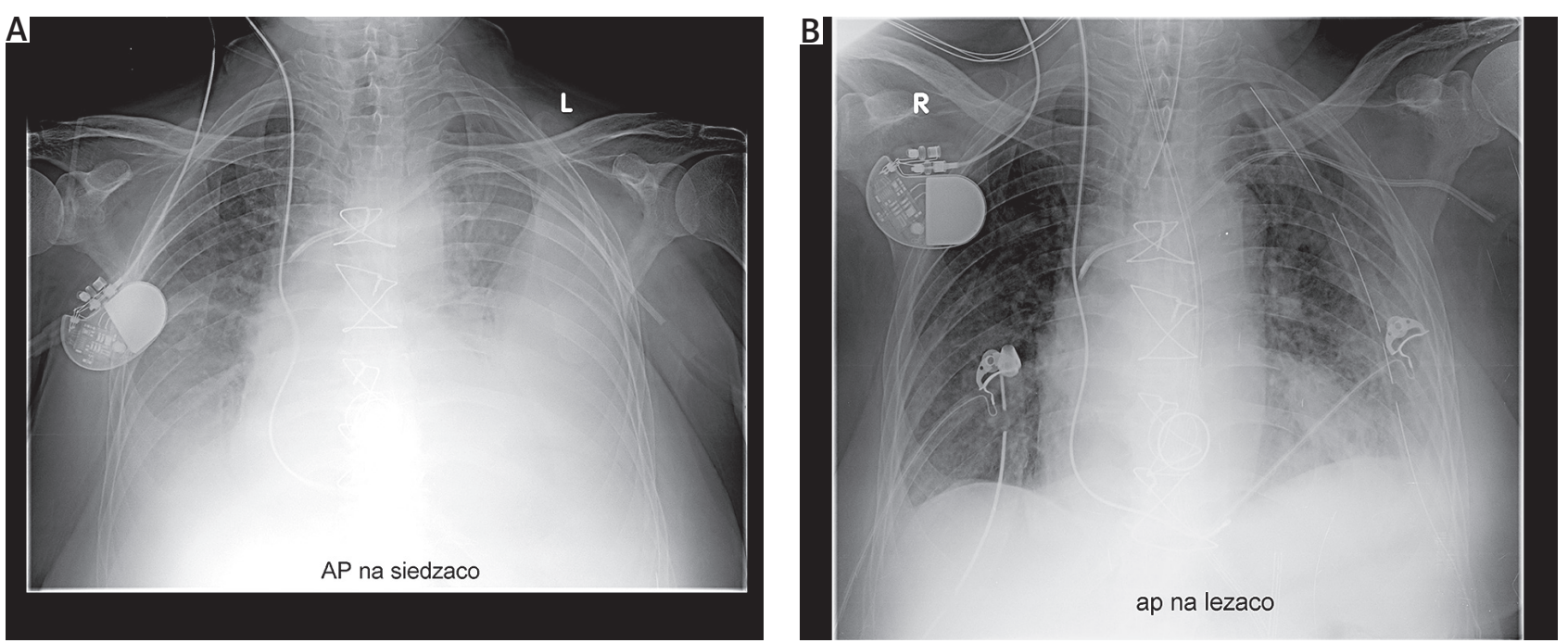

Fig. 4. A - Chest X-ray with the diagnosis of left-sided hemothorax, B - control X-ray after video-assisted thoracic surgery

ter lung function [13]. In our material, VATS proved to be an effective procedure for hemothorax evacuation in patients after sternotomy. The main advantage of this method appears to be the use of a minimally invasive approach not associated with the sternotomy wound.

Access through median sternotomy ensures the evacuation of fluid and clots within the mediastinum and both pleural cavities. It is used when hemothorax is accompanied by mediastinal hematomas or confirmed sternal instability. The standard management includes the performance of echocardiography and CT in order to exclude the abovementioned changes before qualifying the patient for VATS. These examinations should be used to supplement the clinical picture.

Differential diagnostics should consider pulmonary atelectasis.

Active bleeding can be better managed using sternotomy. The perioperative risk increases with the time that has passed from the primary procedure due to the development of adhesions within the mediastinum, and access to the left pleural cavity poses a particular technical challenge (in patients after coronary artery bypass grafting with the use of the left internal thoracic artery). Such patients (hemodynamically stable in the late postoperative period, with stable sternums and healed postoperative wounds) are good candidates for VATS aiming to evacuate hemothorax. The VATS is an effective procedure for evacuating hemothorax.

\section{Disclosure}

Authors report no conflict of interest.

\section{References}

1. Głowacki J, Filipowski M, Lewandowski R, Wojtacha J, Hawranek M, Greiff M, Miszalski-Jamka K, Jackowska Z, Rokicki W. Krwiak pourazowy lewej jamy opłucnowej powikłany krwiakiem śródpiersia i odmą opłucnową u młodego dorosłego - opis przypadku. Kardiochir Torakochir Pol 2010; 7: 341-343.

2. Kumar S, Rathi V, Rattan A, Chaudhary S, Agrawal N. VATS versus intrapleural streptokinase: a prospective, randomized, controlled clinical trial for optimum treatment of post-traumatic residual hemothorax. Injury 2015; 46: 1749-1752.

3. Dziedzic D, Orłowski T. The role of VATS in lung cancer surgery: current status and prospects for development. Minimally Invasive Surgery 2015, 2015 938430.

4. Mowery NT, Gunter OL, Collier BR, Diaz JJ Jr, Haut E, Hildreth A, Holevar M, Mayberry J, Streib E. Practice management guidelines for management of hemothorax and occult pneumothorax. J Trauma 2011; 70: 510-518.

5. Little AG, Merrill WH, de Hoyos A. Complications in Cardiothoracic Surgery, Avoidance and Treatment. $2^{\text {nd }}$ ed. Blackwell Publishing Ltd 2010; 308.

6. McKenna Jr RJ, Houck W, Fuller CB. Video-assisted thoracic surgery lobec tomy: experience with 1,100 cases. Ann Thorac Surg 2006; 81: 421-426.

7. Hoksch B, Ablassmaier B, Walter M, Müller JM. Complication rate after thoracoscopic and conventional lobectomy. Zentralbl Chir 2003; 128: 106-110.

8. Onaitis MW, Petersen RP, Balderson SS, Toloza E, Burfeind WR, Harpole Jr DH, D'Amico TA. Thoracoscopic lobectomy is a safe and versatile procedure: experience with 500 consecutive patients. Ann Surg 2006; 244: 420-425.

9. Swanson SJ, Herndon JE $2^{\text {nd }}$, D'Amico TA, Demmy TL, McKenna RJ Jr, Green MR, Sugarbaker DJ. Video-assisted thoracic surgery lobectomy: report of CALGB 39802 - a prospective, multi-institution feasibility study. J Clin Oncol 2007; 25: 4993-4997.

10. Demmy TL, Curtis JJ. Minimally invasive lobectomy directed toward frail and high-risk patients: a case-control study Ann Thorac Surg 1999; 68: 194-200.

11. McVay CL, Fuller CB, Houck W, McKenna Jr R. VATS anatomic pulmonary resection in octogenarians. Am Surg 2005; 71: 791-793.

12. Nakajima J, Takamoto S, Kohno T, Ohtsuka T. Costs of videothoracoscopic surgery versus open resection for patients with of lung carcinoma. Cancer 2000; 89 (11 Suppl): 2497-2501.

13. Nakata M, Saeki H, Yokoyama N, Kurita A, Takiyama W, Takashima S. Pulmonary function after lobectomy: video-assisted thoracic surgery versus thoracotomy. Ann Thorac Surg 2000; 70: 938-941. 